Cornell University

School of Industrial and Labor Relations

Center for Advanced Human Resource Studies
CAHRS at Cornell University 187 Ives Hall

Ithaca, NY 14853-3901 USA

Tel. 607 255-9358

www.ilr.cornell.edu/CAHRS

\title{
A Resource-Based View of International Human Resources: Toward a Framework of Integrative and Creative Capabilities
}

Shad S. Morris

Scott A. Snell

Patrick M. Wright

Working Paper 05 - 16 


\title{
A Resource-Based View Of International Human Resources: Toward A Framework of Integrative and Creative Capabilities
}

\author{
Shad S. Morris \\ Cornell University \\ School of Industrial and Labor Relations \\ 393 Ives Hall \\ Ithaca, NY 14853 \\ (607) 255-7622 \\ ssm27@cornell.edu
}

\author{
Scott A. Snell \\ Cornell University \\ Center for Advanced Human Resource Studies (CAHRS) \\ 393 Ives Hall \\ Ithaca, NY 14853 \\ (607) 255-4112 \\ scott.snell@cornell.edu \\ Patrick M. Wright \\ Cornell University \\ Center for Advanced Human Resource Studies (CAHRS) \\ 393 Ives Hall \\ Ithaca, NY 14853 \\ (607) 255-3429 \\ pmw6@cornell.edu
}

http://www.ilr.cornell.edu/cahrs

This paper has not undergone formal review or approval of the faculty of the ILR School. It is intended to make results of Center research available to others interested in preliminary form to encourage discussion and suggestions.

Most (if not all) of the CAHRS Working Papers are available for reading at the Catherwood Library. For information on what's available link to the Cornell Library Catalog:

http://catalog.library.cornell.edu if you wish. 


\begin{abstract}
Drawing on organizational learning and MNC perspectives, we extend the resourcebased view to address how international human resource management provides sustainable competitive advantage. We develop a framework that emphasizes and extends traditional assumptions of the resource-based view by identifying the learning capabilities necessary for a complex and changing global environment. These capabilities address how MNCs might both create new HR practices in response to local environments and integrate existing HR practices from other parts of the firm (affiliates, regional headquarters, and global headquarters). In an effort to understand the nature of such capabilities, we discuss aspects of human capital, social capital, and organizational capital that might be linked to their development.
\end{abstract}




\section{Introduction}

Few will argue against the importance of international human resource management (IHRM) in today's multinational corporation (MNC). A wide range of issues-that varies from global sourcing and off-shoring to regional trade agreements and labor standards to strategic alliances and innovation-all point to the vital nature of IHRM in today's global economy. In fact, some observers have suggested that how firms manage their work forces is among the strongest predictors of successful versus unsuccessful MNCs (cf., Bartlett \& Ghoshal, 1989; Doz \& Prahalad, 1986; Hedlund, 1986).

Researchers have adopted a number of different theoretical approaches for studying IHRM. Not surprisingly, the resource-based view (RBV) of the firm has emerged as perhaps the predominant perspective (Wright, Dunford, and Snell, 2002). RBV is particularly attractive to IHRM researchers in that it focuses directly on the potential value of a firm's internal asset stocks for conceiving and executing various strategies. This perspective departs from traditional I/O economic models of competitive advantage that focus on the structure of markets as the primary determinant of firm performance (Barney, 1991; Wernerfelt, 1984). Also in contrast with I/O economic models, the RBV is based on the assumption that resources are (1) distributed heterogeneously across firms and (2) remain imperfectly mobile over time. Because these asset stocks are unequal, there is the potential for comparative advantage. And when the resources are immobile, that advantage may be difficult to appropriate or imitate, thereby conferring a sustainable advantage

In the context of MNCs, the premises of resource heterogeneity and immobility have particular relevance. While the RBV typically focuses on resource heterogeneity across firms, MNCs are unique in that they possess heterogeneity within their asset stocks as well. Because they operate in multiple environments, MNCs are likely to possess variations in both their people and practices that reflect local requirements, laws, and cultures. This variation is a potential source of advantage at a local level, and can provide a global advantage to the MNC as a whole if the knowledge, skills, and capabilities can be leveraged appropriately. 
However, while heterogeneous resources are potentially immobile across firms, they may also be immobile within firms (MNCs). Given that scholars have consistently noted the difficulties of integrating people and practices within MNCs (e.g., Szulanski, 1996; McWilliams, Van Fleet, \& Wright, 2001), the challenge of integration remains one of the more perplexing organizational and strategic issues. It is therefore somewhat surprising that IHRM researchers have not addressed this issue more directly.

The purpose of this chapter is to summarize the literature on RBV and IHRM by addressing the ways in which resource heterogeneity and immobility provide potential advantages to MNCs. However, we also hope to extend the RBV in this context by addressing some of the primary challenges of-and capabilities needed to-create resources and integrate them across business units within the MNC. In this sense, we draw upon the knowledge-based view of the firm (KBV) and organizational learning perspectives to look at how practices are created and integrated on a global scale (Grant, 1996; Teece, Pisano, \& Shuen, 1997). To organize this discussion, we break the chapter down into three parts: First, we review how the RBV has been applied to IHRM issues to date and discuss the underlying assumptions of this research. Second, we extend the RBV logic to more appropriately deal with issues of practice integration and creation within a globally dynamic environment by turning focus to aspects of learning capabilities. Finally, we discuss the implications for future research and where this extended view of RBV might improve research on a firm's human resources.

\section{IHM, People, Practices, And Competitive Advantage}

Discussions of IHRM within the RBV framework focus on both the workforce (i.e., the people) as well as the HR function (i.e., the structures, policies and practices) (e.g., Evans, Pucik, \& Basoux, 2002; Fey \& Bjorkman, 2001; MacDuffie, 1995; Schuler, Dowling, \& De Cieri, 1993). To have a sustainable competitive advantage a firm must first possess people with different and better skills and knowledge than its competitors or it must possess HR practices that allow for differentiation from competitors. Second, these practices or skills and abilities should not be easy for competitors to duplicate or imitate (Wright, Dunford, \& Snell, 2001). 


\section{Managing Global Workforces}

Building on the assumptions of heterogeneity and immobility, scholars systematically stress the strategic contributions of people's knowledge and skills to the performance of firms and sustained competitive advantage (Boxall, 1996). In fact, Barney (1991) developed a model to show how specific assets can be strategically identified to lead to sustainable competitive advantage. Building on this model, McWilliams, Van Fleet, and Wright (2001) argue that human resources, defined as the entire pool of employees, present a unique source of advantage in comparison to domestic labor pools in terms of value, rarity, inimitability, and nonsubstitutability (VRIN).

Given the VRIN framework, McWilliams et al. (2001) argued that firms can benefit from a global workforce in two ways: (1) capitalizing on the global labor pools, and (2) exploiting the cultural synergies of a diverse workforce. First, global (heterogeneous) labor pools potentially provide superior human capital. This is because firms can draw from different labor pools to match the different needs of the firm (Bartlett \& Ghoshal, 1989). For example, some labor pools may have workers who, on average, have higher cognitive ability or have had greater access to education and training. An MNC could potentially draw from the highest quality labor pools for those functions that require high cognitive ability and education and training (McWilliams et al., 2001).

Second, the use of heterogeneous labor pools potentially increases the quality of global business decision making. When an MNC draws from its multiple labor pools it has the potential to a build diverse and flexible cadre of managers that are better able to bring different perspectives to a decision than a management group based solely from the parent country (Ricks, 1993). That diversity also enables management to be flexible in applying their skills throughout the different parts of the firm. Wright and Snell (1998) discussed theses advantages in terms of resource flexibility and coordination flexibility.

While McWilliams et al. (2001) highlighted the benefits of human resource heterogeneity and immobility; they also point out the difficulty in transferring and integrating these resources 
within the MNC. Drawing on Szulanski's (1996) concept of stickiness, they note that the exchanges are made more difficult by "the lack of absorptive capacity of the recipient, causal ambiguity, and an arduous relationship between the source and the recipient" (Szulanski, 1996: 36). Yet, little research exists discussing how internal stickiness can be overcome in order to maximize the benefits of a global workforce while overcoming the challenges of integration and coordination.

\section{Managing Global HR Functions}

Placing people as the source of sustainable competitive advantage moves us to the dilemma of how best to manage their knowledge, skills, and abilities. Within the RBV literature, issues of resource heterogeneity and immobility underlie the inevitable tension between local responsiveness and global integration in MNCs (cf., Bae \& Lawler, 2000; Brewster, 1999; Fey \& Bjorkman, 2001; Sparrow, Schuler \& Jackson, 1994). Local responsiveness and the value derived from customization implies variation-i.e., heterogeneity-within the MNC. Global efficiency, on the other hand, requires integration across business units. However, given the assumption of resource immobility, this integration is not always easy to achieve.

Schuler et al. (1993) captured the essence of these tradeoffs by highlighting the relationships between internal operations and interunit linkages. From the standpoint of internal operations, each overseas affiliate must operate as effectively as possible relative to the competitive strategy of the MNC. This means that these affiliates can offer advantages to the MNC by recognizing and developing HR practices that are appropriate for their local markets, employment laws, cultural traditions, and the like.

While internal operations at the local level are important, the MNC must also establish interunit linkages to gain efficiencies of scale and scope across several different countries. This suggests that while overseas affiliates can generate advantages locally, there are also substantial advantages that can be gained globally through integrated HR practices. Each is important, but each carries with it a different set of organizational requirements. These requirements point directly to issues relevant for HRM. 
Extending these ideas, Taylor, Beechler, and Napier (1996) describe how MNCs might develop a more integrative approach to HRM. The objective of this strategy is to share best practices from all parts of the firm (not just corporate) to create a worldwide system. While there are allowances for local differentiation, the focus is on substantial global integration.

Differentiation provides both the potential for local response and customization, as well as the variety of ideas and practices needed for innovation at the global level.

However, integration through coordination, communication, and learning is not always easily achieved in this context. Ironically, the very characteristics that provide resource-based advantage at the local level actually complicate integration at the global level. The ability of firms to gain efficiencies of scope and scale at a global level is made more difficult by resource heterogeneity, and this challenge is exacerbated by resource immobility.

The challenge then for the transnational firm is to identify how firms can preserve variety (and local customization) while simultaneously establishing a foundation for integration and efficiency. As mentioned by McWilliams et al. (2001) very few scholars have addressed the "stickiness" issue involved in balancing the global and local tension. Taylor et al. (1996) allude to such integration difficulties when they note:

"The reason firms move toward an exportive rather than an integrative SIHRM orientation...is that the mechanism to identify and transfer the best HRM practices in their overseas affiliates are not in place. Such mechanisms as having regional or global meetings of affiliate HR directors, transferring HRM materials (e.g., performance appraisal forms to affiliates) or posting of the HR director of the affiliates to the HQs of the firm were not developed..." (p. 972).

These same capability issues are raised by McWilliams et al. (2001) when they discuss the major causes of internal stickiness being lack of absorptive capacity, causal ambiguity, and arduous relationships between the source and recipient. In both examples, barriers to global practice integration are raised and discussed, but not resolved. This issue is addressed more fully below. 


\section{IHM And Capabilities}

Given the importance-and difficulty_of integrating human resources at a global level, while preserving the uniqueness and heterogeneity at the local level, it seems reasonable to discuss these issues in the context of competitive capabilities. Based on the knowledge based view (KBV) of firms, that emphasizes the need to acquire and integrate knowledge, we suggest two such capabilities (see Figure 1). First, knowledge integration capability refers to a firm's ability to transfer and coordinate human resources across affiliates in a way that utilizes economies of scale and scope while allowing and promoting responsiveness to the local environment. Second, knowledge creation capability refers to a firms' ability to create new and potentially innovative practices at the local level.

\section{Figure 1}

IHRM: People, Practices, and Capabilities

\begin{tabular}{|c|c|c|c|}
\hline Focus & Theories & Strategic Question & Sources \\
\hline People & $\begin{array}{l}\text { RBV: } \\
\text { Focus on individual } \\
\text { resources of knowledge, } \\
\text { skills, and abilities }\end{array}$ & $\begin{array}{l}\text { Workforce: } \\
\text { What are the knowledge, skills, and } \\
\text { abilities that are heterogeneous and } \\
\text { immobile? }\end{array}$ & $\begin{array}{l}\text { McWilliams, Van } \\
\text { Fleet, \& Wright, } \\
2001\end{array}$ \\
\hline Practices & $\begin{array}{l}\text { RBV and Competencies: } \\
\text { Focus on combined } \\
\text { resources of HR practices }\end{array}$ & $\begin{array}{l}\text { HR Practices and Systems: } \\
\text { What are the HR practices and systems } \\
\text { that are heterogeneous and immobile? }\end{array}$ & $\begin{array}{l}\text { Taylor, Beechler, \& } \\
\text { Napier, } 1996\end{array}$ \\
\hline Capabilitie & $\begin{array}{l}\text { KBV and Organizational } \\
\text { Capabilities: } \\
\text { Focus on learning processes } \\
\text { and capabilities }\end{array}$ & $\begin{array}{l}\text { Learning Capabilities: } \\
\text { How can HR practices and systems be } \\
\text { created and integrated to preserve } \\
\text { heterogeneity and immobility? }\end{array}$ & $\begin{array}{l}\text { Chadwick \& } \\
\text { Cappelli, } 1999\end{array}$ \\
\hline
\end{tabular}

\section{Knowledge Integration Capability}

Ironically, while learning capability is one of the key dimensions of the Bartlett and Ghoshal (1989) framework of transnational organizations, most IHRM researchers have made only passing mention of how firms share and integrate best practice within the MNC. Snell, Youndt, and Wright (1996) argued that, particularly in dynamic environments, organizational learning may be the only way to ensure that resources sustain their value and uniqueness over 
time. In essence, the capability to integrate HR practices better than competitors may be a key source of sustainable competitive advantage (cf., Kogut \& Zander, 1992). In the sections below, we frame the key factors underlying knowledge integration capability in terms of organizational capital, social capital, and human capital.

Organizational Capital. Youndt, Subramaniam, and Snell (2004) define organizational capital as the institutionalized knowledge and codified experiences residing within an organization. Artifacts of organizational capital include an organization's reliance on manuals and databases to preserve knowledge, along with the establishment of structures, processes, and routines that encourage repeated use of this knowledge (Hansen, Hohria, \& Tierney, 1999). As an integration mechanism, organizational capital allows the firm to preserve knowledge as incoming employees replace those leaving. An example of such an artifact might be a "lessons learned" database to ensure that lessons learned by one group can be made accessible for all groups.

Based on MNC research, in order to improve the integration of knowledge within an MNC relative to the speed of its diffusion or imitation by competitors, firms invest in ways to make knowledge explicit by encoding its use and replicating it in rules and documentation (Kogut \& Zander, 1993). Other forms of organizational capital are likely to represent detailed, company-wide routines on how new HR practices should be integrated by all affiliates. These routines may detail how practices should be shared to reduce the variance and time it takes to implement each new approach, and thereby, improve the overall efficiency of knowledge integration (March, 1991). Similarly, organizations typically implement information systems to provide affiliates with a common platform for HR processes and practices (Snell, Stueber \& Lepak, 2002). These systems, processes, and routines ensure that: (1) practices are implemented routinely through established data collection procedures and (2) practices are rapidly disseminated throughout the entire MNC with minimal costs (Daft \& Weick, 1984). In terms of integration capability, then, organizational capital provides a basis for sharing and 
institutionalizing knowledge across affiliates. However, it may work against efforts to preserve heterogeneity at the sub-unit level.

Social Capital. Social capital—defined as the knowledge embedded within social networks-also plays a potentially valuable role in the integration capability of MNCs (Nahapiet \& Ghoshal, 1998). For example, Szulanski (1995) found that one of the biggest obstacles to transfer knowledge in MNCs is the poor relationship between sources and recipients of information. Along this line, Ghoshal and Bartlett (1989) empirically showed that knowledge sharing and integration could not occur without the existence of strong social connections.

The importance of social capital for integration capability is found in research by Kostova and Roth (2002), who concluded that successful practice adoption is largely dependent upon relationships based on trust and shared identity. Trust provides the motive to interact with others, while shared identity provides an overlapping understanding of what is important to share. Both of these elements of social capital would seem vital for integration capability. And importantly, neither of them would de facto require the loss of local autonomy.

Human Capital. While organizational and social capital are both potentially important resources underlying a firm's integration capability, Teece (1977) argued that one of the principle obstacles to transfer and integration is lack of prior experience and knowledge (i.e., human capital). Research by Szulanski (1996) and Tsai (2002), for example, has shown that knowledge sharing and integration is facilitated when respective parties have the absorptive capacity or prior experience to understand related ideas (Szulansk, 1996; Tsai, 2002). In the context of MNCs, Haas (2004) showed that groups with large amounts of international experience are more likely to integrate knowledge from other parts of the organization than those that do not. Similarly, Gregersen and Black (1992) found that not only is international experience important for integration, but when it is coupled with experience in corporate headquarters affiliates are more likely to maintain allegiance to the overall goals of the firm.

These international and corporate skills and knowledge are often gained through transfers and rotational assignments that enable the HR function to develop a more complex 
and global orientation. This provides them with the ability to more systematically manage the integration process (Kedia \& Bhagat, 1988). Such forms of human capital can also correct any tendency of HR subunits to assume that the situation in the host country is unique; thus avoiding the not-invented-here syndrome.

The upshot of this discussion s is that a firm's integration capability likely depends on a combination of human, social, and organizational capital. Social and organizational capital are alternative_-and potentially complementary_resources for knowledge and practice sharing. Human capital, in turn, is important for absorbing or acquiring that knowledge. As firms develop the capability to integrate existing practices they potentially can achieve economies of scale and scope through HRM. And when these integrative mechanisms preserve resource heterogeneity at a local level, it may lead to a more rapid response to a global environment and greater potential for competitive advantage.

Figure 2

Capabilities: Creative and Integrative

\begin{tabular}{|c|c|c|c|}
\hline Focus & Market Assumption & $\begin{array}{c}\text { Value } \\
\text { Proposition }\end{array}$ & Sources \\
\hline $\begin{array}{l}\text { Integrative } \\
\text { Capabilities }\end{array}$ & $\begin{array}{l}\text { Stable Market: } \\
\text { Resources must be } \\
\text { combined and } \\
\text { integrated to maintain } \\
\text { an advantage }\end{array}$ & $\begin{array}{l}\text { Combining resources in } \\
\text { ways that others cannot } \\
\text { copy creates benefits } \\
\text { arising from scarcity }\end{array}$ & $\begin{array}{c}\text { Taylor, Beechler, \& Napier, } \\
\text { 1996; McWilliams, Van } \\
\text { Fleet, \& Wright, } 2001\end{array}$ \\
\hline $\begin{array}{c}\text { Creative } \\
\text { Capabilities }\end{array}$ & $\begin{array}{l}\text { Dynamic Market: } \\
\text { Resources must be } \\
\text { reconfigured and } \\
\text { created to maintain an } \\
\quad \text { advantage }\end{array}$ & $\begin{array}{l}\text { Developing new } \\
\text { resources that } \\
\text { competitors don't yet } \\
\text { have creates benefits } \\
\text { arising from innovation }\end{array}$ & $\begin{array}{c}\text { Chadwick \& Cappelli, 1999; } \\
\text { Snell, Youndt, and Wright; } \\
1996\end{array}$ \\
\hline
\end{tabular}




\section{Knowledge Creation Capability}

In the context of organizational learning and the $\mathrm{KBV}$, it is important to distinguish knowledge integration capability from knowledge creation capability. Just because a firm is able to integrate practices across affiliates does not mean that it will be able to create new practices as well (See Figure 2). Creation capabilities allow the MNC to develop new practices that lead to resource heterogeneity in the first place. While few HRM researchers have mentioned the importance of integration mechanisms, fewer still have discussed the importance of creation mechanisms that renew a firm's stock of HR practices. This is despite the fact that as firms continually integrate practices, it is imperative that new practices are created and developed that allows for innovation and continuous improvement in a changing environment. Therefore, in global environments characterized by rapid change and increasing competition, static concepts of heterogeneity may no longer be sufficient to explain (and sustain) a competitive advantage.

An ongoing debate in strategy is whether any static view of resources can really explain a competitive advantage that is sustainable over time (Lippman \& Rumelt, 1982). For example, Grant (1996) argues that idiosyncratic advantages naturally erode over time. This debate is especially relevant in the global environment where what might create a competitive advantage at one point in time or in one location, may not at another point in time or location. Hence, it is vital that MNCs develop the capability to create and renew HR practices in order to maintain a competitive advantage.

Ghoshal \& Bartlett (1988) stated that MNCs "create" new products, practices, or systems locally, using specific mechanisms to respond to local circumstances. Creating local HR practices lies at the heart of an MNC's capability to be responsive to the unique and changing opportunities of different environments. Below, we discuss how human capital, social capital, and organizational capital might influence the knowledge creation capability of new HR practices. (See Figure 3 for an overview of mechanisms that influence knowledge integration and creation capabilities). 


\section{Figure 3}

Capabilities: Human Capital, Social Capital, Organizational Capital

\section{Human Capital Social Capital Organizational Capital}

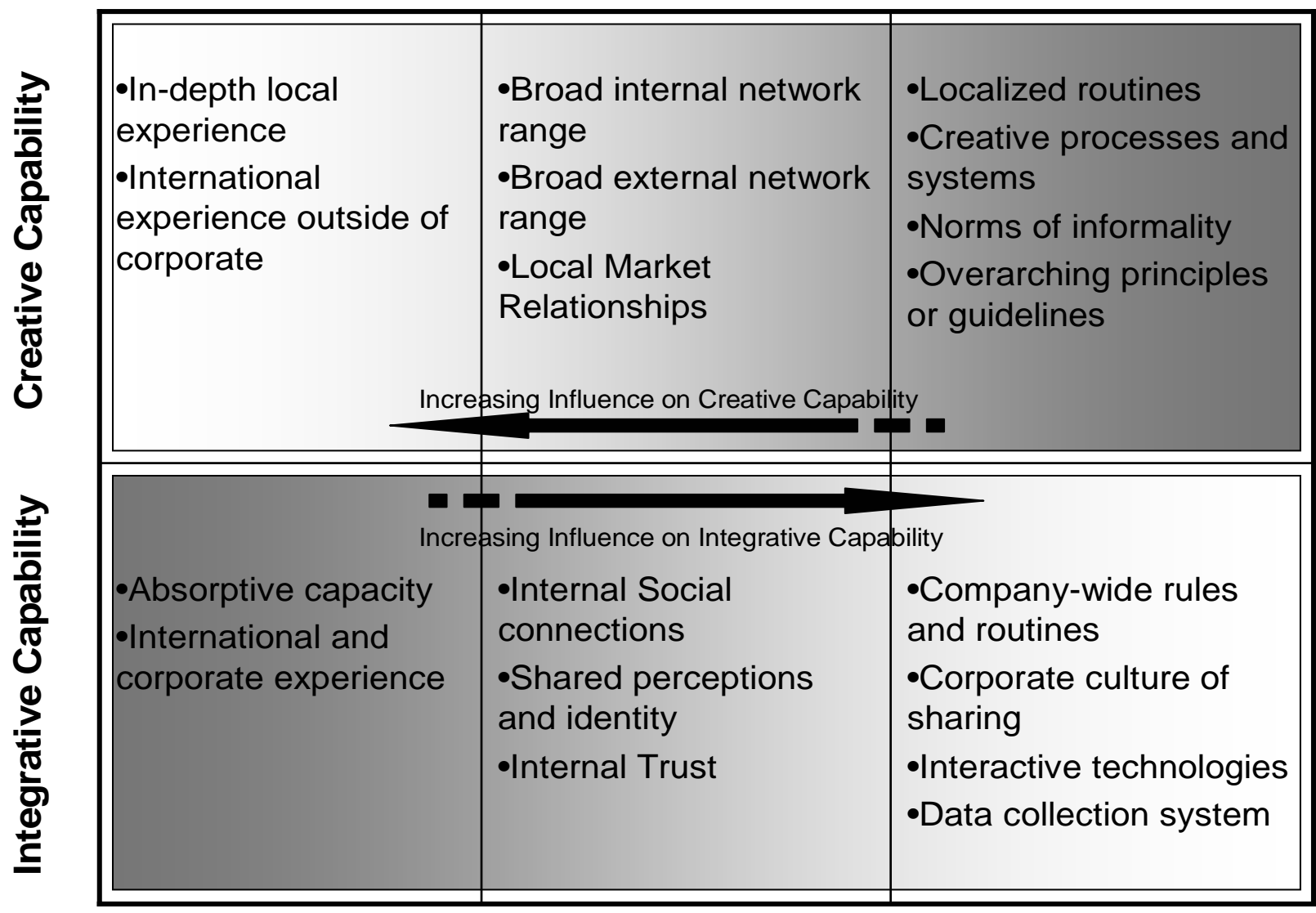

Human Capital. The knowledge and experience-i.e., human capital—of the people within the HR function is a key factor in new HR practice creation-whether of new practice ideas, or of improvements in the practices (Lepak \& Snell, 1999). For example, HR functions possessing large amounts of local knowledge and experience should be able to effectively create practices on their own in response to the various, changing environments. This localized experience helps them to understand the needs of local clients and suppliers, which allows them to develop practices that are unique to each region or country, and hence, heterogeneous across the firm. 
International experiences are also important for creating new HR practices. For example, because international experience is often highly valued in MNCs (e.g., Mendenhall \& Stahl, 2000), people with international skills and knowledge are more likely to be seen by others as being confident and willing to share divergent opinions and advocate for their own position (Stasser, Stewart, \& Wittenbaum, 1995). Moreover, Gregersen \& Black (1992) showed that people with strong experience in many international settings and limited experience in corporate are more likely to make changes based on local demands rather than pressures from central parts of the firm. This is most likely due to the people's array of international experiences that have detached them from an allegiance with the company as a whole.

Social Capital. Specific aspects of social capital have been argued to play a role in knowledge creation. For example, while Hansen (2002) argued that social networks provide an important conduit for the sharing of knowledge, he also argued that such networks play a role in knowledge creation because they inform network members about the existence, location, and significance of new knowledge. Burt (1982) found that networks comprising a broader range of contacts will have a more heterogeneous base of information and knowledge to draw from. While such wide networks may not always facilitate a deep flow of knowledge, they offer different reference points for HR members to make comparisons and explore new ideas.

A firm's ability to find new opportunities is likely to be a function of multiple local contacts. HR affiliates often have critical links with local vendors and, perhaps, competing HR groups that allow them to pursue local opportunities (Bartlett \& Ghoshal, 1989; Hedlund, 1986). Birkinshaw (1997) refers to these as relationships within the 'local market'. Within the local market an affiliate is likely to be embedded in different types of relationships (Ghoshal \& Bartlett, 1990; Ghoshal \& Nohria, 1989). McEvily and Zaheer (1999) argue that because each part of the MNC maintains different local patterns of network linkages, they are exposed to new knowledge, ideas, and opportunities.

Organizational Capital. In many cases, organizational capital may actually hinder knowledge creation capability. The formalized processes, systems, structures, etc. have a 
tendency to reinforce existing routines and obviate against variation and change that engender creativity. However, in some instances, organizational capital may facilitate flexibility in the course of actions that allow a firm to attend to environmental cues. This is especially true when employees are encouraged to take action that supersede company-wide, standardized routines in favor of localized response that allows knowledge assimilation from the local environment (Daft \& Weick, 1984). For example, parts of the firm may develop creative processes and systems to identify problems, develop hypotheses, communicate ideas to others, and contradict what would normally be expected (Torrence, 1988). Grant (1996) argued that such creative routines and processes offer an efficient framework for people to create new, situation-specific practices by utilizing local perspectives in developing practices for the firm.

Though potentially problematic for the integrative capability, localized routines and creative processes help affiliates relate better with local vendors, clients, and competitors by providing a set of expectations and processes that encourage HR groups to turn to the surrounding environment. For example, an HR affiliate may have developed a simple manual or informal norm of what to do when developing a new practice. Such a routine is likely to leave many gaps in exact steps to follow, but provide an overview or value to help the HR group be innovative. This simple routine allows the local HR group to assimilate knowledge more quickly from its employees and develop practices to meet their needs.

In summary, these aspects of human capital, social capital, and organizational capital help us identify how the knowledge integration and creation capabilities might occur within an MNC. Some of these forms of capital are more useful depending upon the capability it is supporting, and ironically, some of these mechanisms that influence integration might actually hinder knowledge creation and vice versa. For example, firms heavy in local knowledge and experiences and weak in international experiences might have a negative affect on a firm's ability to integrate practices across the various parts of the firm. Such strong human capital is likely to promote the not-invented-here syndrome through the affiliate's strong belief and experience base dealing exclusively with the local environment. Similarly, rigid forms of 
organizational capital, in terms of standardized routines and shared electronic databases, might deter the various parts of HR to develop and create practices on their own. This could largely stem from the fact that so much structure and support for integration is in place that HR groups fail to find time to bring about new practices or adapt existing practices to the local environment.

\section{Implications For Research And Theory}

The unique complexities and challenges faced by today's global firms present different implications for the RBV and its application to strategic IHRM. For example, because a large amount of the international management literature focuses on variances in cultural, geographical, and institutional pressures; the implications for applying the RBV become more complex. As MNCs struggle to create and integrate their practices across borders, they are faced with unique challenges that either push for global efficiency or local responsiveness. These challenges open the discussion for ways to actually manage both the creation and integration of knowledge on a global scale.

This means that the questions typically asked by strategic IHRM scholars (e.g., HR practices and performance) should be augmented with questions of how HR practices are created and integrated in ways that lead toward resource heterogeneity and immobility. To create a sustainable competitive advantage firms must not only be able to respond to their local environments or standardize their practices across the firm. They must be able to balance a tension of practice heterogeneity through local practice creation and immobility of those practices through their integration across the firm.

One theoretical implication of this discussion calls for a greater understanding of the rents found through the creation and integration of HR practices. As Chadwick and Dabu (2004) explain, a marriage of rent concepts with theories of the firm (i.e., RBV) is essential to describing firm's competitive advantages and particularly in understanding how actors within firms can take conscious steps to toward a sustainable competitive advantage. The current strategic IHRM literature strongly alludes to the importance of integration and being able to 
organize heterogeneous resources in a way that is difficult for competitors to imitate. The assumption here is that heterogeneity and immobility of resources creates greater performance or rents arising from scarcity-Ricardian rents (cf., Carpenter, Sanders, Gregersen, 2001). In essence, Ricardian rents can be rooted in the cross-border integration of various HR practices. The integration of such practices not only assures that some of them will be unique to the firm, but that they will be difficult for others to imitate-making them scarce in the market.

The advantages that come from constant creation of HR practices operates under a different principle than traditional resources leading to Ricardian rents. Rather than rents arising from scarcity, the creation capability perspective emphasizes rents arising from market discontinuities_Schumpeterian rents (cf., Carpenter et al., 2001). Schumpeterian rents derive from a firm's ability to exploit or leverage resources to address changing environments (Teece et al., 1997; Amit \& Schoemaker, 1993). Based on Schumpeterian rents, a focus on the continuous creation of resources can enable a firm to achieve competitive advantage on a sustainable basis by developing new practices that lead to practice heterogeneity across a complex and ambiguous global network. Hence, as mentioned by Lado and Wilson (1994) and Teece et al. (1997), turning to these dynamic capabilities as an extended approach to the RBV offers a closer understanding of the actual sources of competitive advantage in a changing global environment.

While we discuss the main mechanisms driving knowledge creation and integration (Grant, 1996), aspects of integration tend to focus on a broad array of learning processes, including knowledge sharing, transfer, codification, adoption, and/or institutionalization. Further research should look at how different aspects of the integration process might be influenced by specific human, social, and organizational capital mechanisms. For example, Hansen and Haas (2001) showed that many firms have little difficulty in sharing knowledge across various units of the firm, but that the actual application or institutionalization of this knowledge is a completely different matter. While other scholars such as Kogut and Zander (1992) and Schulz (2001) have theoretically separated integration to include transfer and integration (or combination), very 
little practical research has been done on what factors might influence the transfer and what factors might influence the integration of knowledge. Clearly, there must be differences since research such as Hansen and Haas' (2001) notice the disparity in knowledge that is shared and knowledge that is actually applied.

Also, while the ideas presented in this chapter are rooted in theory, empirical research is needed to determine the impact of human, social,, and organizational capital on knowledge creation and integration capabilities. While theory suggests that aspects of all three of these factors will influence both capabilities, it is most probable that aspects of human capital will more strongly influence the creative capability. This is largely due to the fact that people and their knowledge and skills are what allows the different HR affiliates the ability to develop local practices on their own, without interference or supervision from regional or corporate headquarters. Similarly, social and organizational capital should have their strongest influences on the integrative capability. This is due, in part, to the conduits and repositories created from aspects of social capital and organizational capital, respectively. In fact, as we mentioned earlier, some aspects of organizational capital might have a negative effect on the firm's ability to create new practices (knowledge), while some aspects of human capital may have a negative effect on the firm's ability to integrate those practices across affiliates.

\section{Conclusion}

The purpose of this chapter has been to summarize the literature on RBV and IHRM in multinational firms by addressing the ways in which resource heterogeneity and immobility provide potential advantages to MNCs. However, we have also attempted to extend the RBV in this context by addressing some of the primary challenges of-and capabilities needed tointegrate resources across business units within the MNC.

The solution frequently used by firms has been to standardize HR practices and policies at a global level, but this solves the integration problem while destroying the advantages of local 
variety. The challenge as we see it is identifying how firms can preserve variety (and local customization) while simultaneously establishing a foundation for integration and efficiency.

The ability for HR managers to balance this tension lies in the development of capabilities to create and integrate practices across the global HR function. We extended traditional views of RBV to include aspects of practice integration and creation. Such capabilities allow firms to constantly renew their HR practices in a way that allows them to respond to multiple external pressures while being coordinated and integrated to ensure that these practices drive the firm's sustainable competitive advantage. 


\section{References}

Amit, R., \& Schoemaker, P. J. H. 1993. Strategic assets and organizational rent. Strategic Management Journal, 14: 33-46.

Bae, J., \& Lawler, J. J. 2000. Organizational and HRM strategies in Korea: Impact on firm performance in an emerging economy. Academy of Management Journal, 43: 502-517.

Barney, J. B. 1991. Firm resources and sustained competitive advantage. Journal of Management, 17: 99-120.

Barney, J. B., \& Hoskisson, R. 1989. Strategic groups: Untested assertions and research proposals. Managerial and Decision Economics, 11: 187-198.

Bartlett C. A., \& Ghoshal, S. 1989. Managing Across Borders: The Transnational Solution. Hutchinson Business Books.

Birkinshaw, J. 1997. Entrepreneurship in multinational corporations: The characteristics of subsidiary initiatives. Strategic Management Journal, 18: 207-229.

Boxall, P. 1996. The strategic HRM debate and the resource-based view of the firm. Human Resource Management Journal, 6: 59-75.

Burt, R. S. 1982. Toward a structural theory of action. New York: Academic Press.

Carpenter, M., Sanders, Wm. G., \& Gregersen, H. B. 2001. Bundling human capital with organizational context: The impact of international assignment experience on multinational firm performance and CEO pay. Academy of Management Journal, 44: 493-511.

Chadwick, C., \& Cappelli, P. 1999. Alternatives to generic strategy typologies in strategic human resource management. In L. D. Dyer, P. M. Wright, J. W. Boudreau, and G. T. Milkovich's (eds.) Strategic Human Resource Management in the Twenty-First Century. Stamford, CT: JAI Press.

Chadwick, C., \& Dabu, A. 2004. Rent theories, human assets, human resource management, and competitive advantage. Working Papar.

Daft, R. L., \& Weick, K. E. 1984. Toward a model of organizations as interpretation systems. Academy of Management Review, 9: 284-295.

Doz, Y., \& Prahalad, C. K. 1986. Controlled variety: A challenge for human resource management in the MNC. Human Resource Management, 25: 55-72.

Evans, P. A. L., \& Doz, Y. 1992. Dualities: A paradigm for human resource and organizational development in complex multinationals. In V. Pucik, N. M. Tichy, \& C. K. Barnett's (eds.) Globalizing Management: Creating and Leading the Competitive Organization. New York: Wiley.

Evan, P., Pucik, V., \& Barsoux, J-L. 2002. The global challenge: Frameworks for international human resource management. New York: McGraw-Hill Irwin.

Fey, C. F., \& Bjorkman, I. 2001. The effect of human resource management practices on MNC subsidiary performance in Russia. Journal of International Business Studies, 32: 59-75. 
Ghoshal, S., \& Bartlett, C. A. 1988. Creation, adoption, and diffusion of innovation by subsidiaries of multinational corporations. Journal of International Business Studies, 19: 365388.

Ghoshal, S., \& Bartlett, C. A. 1990. The multinational corporation as an interorganizational network. Academy of Management Review, 15: 603-625.

Grant, R. M. 1996. Toward a knowledge-based theory of the firm. Strategic Management Journal, 17(S2): 109-122.

Gregersen, H. B., \& Black, J. S. 1992. Antecedents to commitment to a parent company and a foreign operation. Academy of Management Journal, 35: 65-91.

Haas, M. R. 2004. Cosmopolitans and locals: Knowledge gathering and project quality in international teams. Working Paper.

Hansen, M. T. 2002. Knowledge networks: Explaining effective knowledge sharing in multiunit companies. Organization Science, 13: 290-302.

Hansen, M. T., \& Haas, M. R. 2001. Compteting for attention in knowledge markets: Electronic document dissemination in a management consulting company. Administrative Science Quarterly, 46: 1-28.

Hedlund, G. 1986. The hypermodern MNC: A heterarchy? Human Resource Management, 25: 9-35.

Kogut, B., \& Zander, U. 1992. Knowledge of the firm, combination capabilities, and the replication of technology. Organization Science, 7: 502-518.

Kogut, B., \& Zander, U. 1993. Knowledge of the firm and the evolutionary theory of the multinational corporation. Journal of International Business Studies, 24: 625-645.

Kostova, T., \& Roth, K. 2002. Adoption of an organizational practice by subsidiaries of multinational corporations: Institutional and relational effects. Academy of Management Journal, 45: 215-233.

Lado, A. A., \& Wilson, M. C. 1994. Human resource systems and sustained competitive advantage: A competency-based perspective. Academy of Management Review, 19: 699-727.

Lepak, D. P., \& Snell, S. A. 1999. The human resource architecture: Toward a theory of human capital allocation and development. Academy of Management Review, 24: 31-48.

Lippman, S., \& Rumelt, R. 1982. Uncertain imitability: An analysis of interfirm differences in efficiency under competition. Bell Journal of Economics, 13: 418-438.

MacDuffie, J. P. 1995. Human resource bundles and manufacturing performance: Organizational logic and flexible production systems in the world auto industry. Industrial and Labor Relations Review, 48: 197-221.

March, J. G. 1991. Exploration and exploitation in organizational learning. Organization Science, 2: 71-87. 
McEvily, B., \& Zaheer, A. 1999. Bridging ties: A source of firm heterogeneity in competitive capabilities. Strategic Management Journal, 20: 1133-1145.

McWilliams, A., Van Fleet, D. D., \& Wright, P. M. 2001. Strategic management of human resources for global competitive advantage. Journal of Business Strategies, 18: 1-23.

Mendenhall, M. E., \& Stahl, G. K. 2000. Expatriate training and development: Where do we go from here? Human Resource Management, 39: 251-266.

Nahapiet, J., \& Ghoshal, S. 1998. Social capital, intellectual capital, and the organizational advantage. Academy of Management Review, 23: 242-266.

Ricks, D. 1993. Blunders in international business. Cambridge: Blackwell Business.

Schuler, R. S., Dowling, P. J., \& DeCieri, H. 1993. An integrative framework of strategic international human resource management. Journal of Management, 19: 419-460.

Schulz, M. 2001. The uncertain relevance of newness: Organizational learning and knowledge flows. Academy of Management Journal, 44: 661-681.

Snell, S.A., Snow, C.C., Canney Davison, S. \& Hambrick, D.C. 1998. Designing and supporting transnational teams: The human resource agenda. Human Resource Management, 37(2): 147-158.

Snell, S.A., Stueber, D. \& Lepak, D.P. 2002. Virtual HR departments: Getting out of the middle. In R. L. Heneman and D.B. Greenberger (eds.) Human resource management in virtual organizations, Information Age Publishing.

Snell, S. A., Youndt, M. A., \& Wright, P. M. 1996. Establishing a framework for research in strategic human resource management: Merging resource theory and organizational learning. Research in Personnel and Human Resource Management, 14: 61-90.

Sparrow, P., Schuler, R. S., \& Jackson, S. E. 1994. Convergence or divergence: Human resource practices and policies for competitive advantage worldwide. International Journal of Human Resource Management, 5: 267-299.

Stasser, G., Stewart, D. D., \& Wittenbaum, G. M. 1995. Export roles and information exchange during discussion: The importance of knowing who knows what. Journal of Experimental Social Psychology, 31: 244-265.

Szulanski, G. 1995. Unpacking stickiness: An empirical investigation of the barriers to transfer best practices inside the firm. Academy of Management Journal, Best Paper Proceedings: 437-442.

Szulanski, G. 1996. Exploring internal stickiness: Impediments to the transfer of best practice within the firm. Strategic Management Journal, 17: 27-44.

Taylor, S., Beechler, S., \& Napier, N. 1996. Toward an integrative model of strategic international human resource management. Academy of Management Review, 21: 959-985.

Teece, D. 1977. Time-cost tradeoffs: Elasticity estimates and determinants for international technology transfer projects. Management Science, 23: 830-837. 
Teece, D. J., Pisano, G., \& Shuen, A. 1997. Dynamic capabilities and strategic management. Strategic Management Journal, 18: 509-534.

Tsai, W. 2002. Social structure of coopetition within a multiunit organization: Coordination, competition, and intraorganziational knowledge sharing. Organization Science, 13: 179-192.

Wernerfelt, B. 1984. A resource-based view of the firm. Strategic Management Journal, 5: 171-180.

Wright, P. M., Dunford, B. B., \& Snell, S. A. 2001. Human resources and the resource based view of the firm. Journal of Management, 27: 701-721.

Wright, P. M., \& McMahon, G. C. 1992. Alternative theoretical perspectives on strategic human resource management. Journal of Management, 18: 295-320.

Wright, P.M. \& Snell, S.A. 1998. Toward a unifying framework for exploring fit and flexibility in strategic human resource management. Academy of Management Review, 22 (4): 756-772.

Youndt, M. A., Subramaniam, M., \& Snell, S. A. 2004. Intellectual capital profiles: An examination of investments and returns. Journal of Management Studies, 41: 335-361. 